\title{
The Comparative Efficiency of Public and Private Power Plants in Pakistan's Electricity Industry
}

\section{Amir Jahan Khan*}

\begin{abstract}
This study estimates a cost function for fossil fuel-based electricity generating plants operating in Pakistan during 2006-11. It employs a six-year panel dataset for 31 plants to estimate the cost function parameters. In the absence of any current evidence on comparative cost performance, the study's attempt to document the economic efficiency of power plants in a large electricity sector is an important contribution to the literature. We find that on average, private nonutility plants (IPPS) are about 17 years younger than utility-owned plants and that the average capacity utilization, as measured by load factor, is higher for private IPPs than for public plants. After controlling for observables, the results show that, for a large part of the system, private plants produce electricity at a lower unit fuel cost than utility-owned public plants. The low efficiency of public plants is likely a result of the lack of operational maintenance and routine repairs. We find that the average fuel price (PRs per MMBTU) is lower for public plants and utility-owned private plants compared to nonutility-owned private plants which is mainly due to the composition of the fuel mix used for power generation. We also find that (i) the partial effect of fuel price changes on the average unit cost is higher for private plants than for public plants and (ii) on average, private plants use relatively expensive fuels compared to public plants. On an average fuel cost comparison, the private sector plants may be better base load plants than public sector plants, though the private sector plants may not be being used as base load plants because of the higher tariffs they change.
\end{abstract}

Keywords: Cost function, utility-owned public plants, load factor, productive efficiency.

JEL classification: D22, D24, L94.

\section{Introduction}

Pakistan's electricity industry has been in transition for the last two decades, with financial constraints to the public sector and the

\footnotetext{
* Assistant Professor, Institute of Business Administration, Karachi, Pakistan.
} 
perceived potential efficiency gains from private enterprise having motivated the federal government to initiate restructuring and privatization in the industry. Since 1994, the government has followed a policy of commissioning new generation capacity in the private sector through nonutility-owned independent power producers (IPPs) (see Government of Pakistan, 1994). The new plants that were set up initially supplied electricity to two vertically integrated state-owned utilities: the Water and Power Development Authority (WAPDA) and the Karachi Electric Supply Corporation (KESC). ${ }^{1}$

The initial reforms introduced in the power generation segment have been adopted without much evidence on the productive efficiency of electricity generation plants or of any comparative advantage across electricity generating establishments, either between private and nonprivate plants or utility- and nonutility-owned plants. The reports issued by the National Electric Power Regulatory Authority (NEPRA) ${ }^{2}$ present technical indicators of the performance of public plants, but no information on their comparative economic efficiency with respect to private plants, particularly after taking into account their distinct characteristics.

Saleem (2007) shows that public ownership of a plant has a negative impact on technical efficiency. The study compares the technical efficiency of public and private plants, using a stochastic frontier framework but without incorporating the cost of inputs. ${ }^{3}$ While the technical efficiency analysis helps understand whether plants can achieve their maximum possible output with a given set of inputs, it does not establish the relative economic efficiency of different sets of power plants. In order to determine which set of plants supplies electricity at the lowest cost, it is important to analyze their performance from an economic efficiency or operational cost perspective. The present study attempts to estimate a cost function for electricity generation plants after controlling for ownership and other relevant characteristics. The estimated unit cost function can indicate the efficiency differential across government-owned and privately owned plants.

The country's electricity industry has tended to perform poorly, with a system characterized by high levels of unreliability, pervasive loadshedding, lack of investment in new capacity (to meet the growth in

\footnotetext{
${ }^{1}$ The KESC was privatized in 2005 while WAPDA remains in an erratic state of transition. Although the former's name was recently changed to "K-Electric," this study still refers to the utility as "the KESC."

${ }^{2}$ NEPRA's annual reports on the state of the industry review the electricity sector's progress.

3 A different mix of inputs on the same isoquant can result in different levels of economic efficiency due to the variation in factor prices.
} 
demand), and system losses (both physical and due to theft). According to the World Bank's enterprise survey for 2010, 65 percent of Pakistani firms see electricity as their main obstacle to growth. Rolling blackouts are common not only in small towns, but also in the major cities.

While there are multiple reasons for the current disorder in the electricity industry, the first stage of an analysis could potentially be to evaluate the economic efficiency of the industry's generation segment. Overall economic inefficiency can be a result of pricing issues ${ }^{4}$ or operational inefficiency in the generation, transmission, or distribution sectors. However, this paper focuses on evaluating the efficiency of the generation segment. This is not to deny that efficiency issues-for instance, in the transmission system or distribution network-have direct and indirect implications for the performance of generating units. That being said, our strategy is to evaluate, using a simple cost function framework, whether in the short run the existing generation capacity is being efficiently utilized or if it operates at the least-cost supply level. The efficient performance of generating units can be considered a necessary condition of the system's overall economic efficiency.

This paper evaluates the comparative performance of private enterprise in the electricity industry of Pakistan. ${ }^{5}$ Private firms operate mainly in the generation segment of the industry and the entrance of private IPPs in Pakistan is in line with international experience. Under certain conditions, entry by new firms increases the competiveness of the electricity generation segment, which is thought to be a relatively competitive segment (Joskow \& Schmalensee, 1983). Arguably, however, if the reforms to encourage private enterprise in electricity generation were framed in order to enhance competition in the industry or if the new capacity was commissioned to cater to the high demand for electricity, then neither function was being fulfilled by the existing set of public plants.

Our findings show that, for the given sample, in the major part of the national grid, nonutility-owned private plants ${ }^{6}$ have performed better than utility-owned public plants. The average unit cost difference between the two sets is economically and statistically significant after controlling for other factors. These findings raise doubts about the policy of using public

\footnotetext{
${ }^{4}$ The price of electricity might not be equal to its marginal cost.

${ }^{5}$ However, this comparison is not intended as a "treatment evaluation" as plant ownership is not exogenous.

6 The terms "nonutility-owned private plant" and "independent power producer" are used interchangeably.
} 
plants as base-load plants, ${ }^{7}$ at least on the basis of an average fuel cost comparison. It appears that the high tariff charged by private firms might prevent them from being used as base-load plants.

The following analysis is divided as follows. Section 2 documents the institutional details of the generation segment while Section 3 highlights the possible implications of institutional structure for the cost of electricity generation. Section 4 describes the data used, Section 5 specifies the empirical model, and Section 6 presents the study's findings. Section 7 provides a brief conclusion.

\section{Electricity Generation and Institutional Structure}

The extensive literature on privatization shows that, over time, private firms become more productive and more profitable (Megginson \& Netter, 2001). They improve their resource allocation and employ modern management practices to increase efficiency within the firm. The KESC, for example, became a profitable organization in 2014 under private ownership. Privatization reforms can create a more competitive environment where firms engage in market-based interaction. Evidence from the US suggests that publicly owned generation plants that were not exposed to a market-based environment gained less from deregulation reforms (Markiewicz, Rose, \& Wolfram, 2004).

According to recent policy briefs, the Government of Pakistan has recommended transferring the ownership of public generation companies (GENCOs) to private management to increase the productive efficiency of the generation segment. This indicates that, at the policy level, there is recognition of the fact that private enterprise may be able to increase efficiency in the electricity industry. The government has cited the persistently poor performance of GENCOs under public management as its rationale for introducing private management. However, to draw any policy implications, we need to estimate both the industry's productive efficiency according to plant ownership as well as the extent of the existing cost efficiency differential between public and private plants.

The reforms and regulation process could have a different impact on the electricity generation operations of the country's two vertically

\footnotetext{
${ }^{7}$ Base-load plants, which run through the year to meet continuous typical demand, are supposed to produce at a lower unit cost. Peak-load plants operate to meet exceptionally high seasonal demand (for instance, during the hot summer months). The latter's cost of production is higher as they are used only for relatively short periods when required. In Pakistan, the distinction between peak-load and base-load is blurred, given the state of perennial unmet demand in the system.
} 
integrated utilities because WAPDA, the main utility, is still under public ownership while the KESC was privatized in 2005. This study draws empirical comparisons between utility-owned government plants and utility-owned private plants. The regulation of the industry has been followed by the corporatization of the public utility-owned plants into GENCOs with changes in managerial practices, while the private utilityowned plants under the KESC have been restructured substantially or new plants commissioned during the sample period.

In order to establish technological homogeneity across plants, our analysis focuses on fossil fuel (oil and gas)-based plants. Further, there are two institutional reasons for analyzing a sample of fossil fuel plants; First, private investment is limited mainly to fossil fuel plants and the bulk of new generating capacity (over the last two decades) comprises fossil fuel plants owned by private firms. In 2002, private generators accounted for about a third of the country's total electricity production; by 2010, this share had reached about two thirds. Second, fossil fuel plants are now the major source of electricity production: about two thirds of the total electricity in the country is produced by fossil fuel, 57 percent of which is generated using oil and 42 percent using gas. Utility-owned plants produce 40 percent of this electricity, while private sector IPPs generate the remaining 60 percent. Almost all the nonutility-owned generating units installed since the 1990s run on fossil fuels, and any new investment in the generation segment (undertaken primarily by private firms) has also targeted plants running on fossil fuels.

The current evidence pertaining to comparative generation performance focuses on technical efficiency (see Saleem, 2007) and suggests that private plants are more technically efficient than public plants (NEPRA, 2010). In the case of fossil fuel plants, the technology involved can be described as the process of generating heat from the fuel input (e.g., oil, gas, or coal) and converting that heat into electricity. The standard measure of fuel efficiency in the electricity industry is the kilowatt-hour $(\mathrm{kWh})$ per unit of heat (British thermal unit or BTU). The regulator's reports support the notion that fuel efficiency is higher for private plants than for public plants (NEPRA, 2010). These findings are not surprising, given the vintage of the IPPs, most of which began operation after the 1994 power policy was issued.

In this context, the present study makes an important contribution to the literature by measuring the economic efficiency of electricity production, given that fuel efficiency covers only the technical aspect of 
efficiency and does not take into account input costs (NEPRA, 2011). It is also important to measure economic efficiency after controlling for other relevant variables that might affect plant performance.

Short-run production efficiency can be evaluated based on the cost of supplying electricity, which will depend on the efficient maintenance of plant equipment, minimum fuel costs, and the efficient utilization of labor (Joskow \& Schmalensee, 1983). In theory, electricity generators connected to the national grid minimize costs, given inputs and electricity prices, irrespective of the given market structure. Deviations from cost minimization behavior can occur due to coordination and agency costs involved in plant management. These costs may be amplified when electricity prices are set by an asymmetrically informed regulator (Laffont \& Tirole, 1993).

The literature shows that management practices are associated with the productivity differential across firms (see Bloom \& Van Reenen, 2010). This applies to power companies in Pakistan as well. The IPPs, for instance, are run by private entrepreneurs, potentially in line with modern management practices that include timely plant maintenance and the employment of suitable staff for various jobs within the organization. Government-owned plants, on the other hand, are under bureaucratic management and are run by government employees with less incentive to improve plant performance. The management of public plants minimizes the cost of operation, but with certain additional constraints. The utilityowned private plants are managed privately (similar to some IPPs), with a properly functioning board or active top management that can potentially pursue policies geared toward upgrading production capacity and closing down older, less efficient plants. ${ }^{8}$

\section{Pakistan's Electricity Industry: Institutional Structure and Costs}

Historically, the electricity industry in Pakistan consisted of two vertically integrated utilities, both of which were government-owned monopolies. Karachi, the largest metropolitan area, was served by the KESC while the rest of the country was covered by WAPDA. ${ }^{9}$ The electricity industry is an important sector of the economy, supplying 15

\footnotetext{
${ }^{8}$ The KESC is closing down old plants and investing in new power generation units.

${ }^{9}$ The industry's status changed with the privatization of the KESC in 2005 and the privatization and restructuring of WAPDA in 1998. WAPDA's fossil fuel-based GENCOs operate under the Pakistan Electric Power Company (PEPCO). In practice, WAPDA is still a vertically integrated utility and has not been successfully restructured (Malik, 2007; NEPRA, 2010).
} 
percent of its final energy consumption. The power generation segment is also a major consumer of primary energy: 30 percent of the country's total gas consumption and 42 percent of its total oil consumption is attributed to fuel consumption within the power generation segment. The electricity industry also receives a substantial subsidy (more than a third of electricity revenues) through the public exchequer. The industry has been in transition for the last two decades, with privatization, deregulation, and corporatization strategies running parallel to one another.

The Government of Pakistan's (1994) power policy allowed private firms to establish power plants and sell electricity to the KESC and WAPDA. This was in line with industry experience, which suggested that the generation segment did not need to be efficiently served by a few suppliers compared to the transmission or distribution segments (Joskow, 1997). The 1994 power policy states that:

Presently the total installed capacity in the country is $10,800 \mathrm{MW}$. This capacity is insufficient to meet the demand on a year round basis... The system is characterized by a high degree of suppressed demand. Conservative projections for annual average increase in the demand are nearly $8 \%$ per year for the next 25 years, ... such an ambitious program cannot be financed in the public sector due to ceilings on Public Sector Development Program (PSDP), and resource mobilization in the private sector is essential for meeting these development targets.

Given that the new private sector investment has been limited to electricity generation, it is useful to examine whether the institutional changes that have taken place have affected the unit cost of energy production between private and public plants differently. Although the fossil fuel-based plants currently connected to the system employ homogenous technology, they vary substantially in terms of age. The private plants are mostly new while the public plants are fairly old. Given that the basic technology used converts heat input derived from oil or gas into electricity, we would expect newer (private) plants to be more technically efficient than older (public) ones, assuming that newer technology can produce a higher output with a given heat input, after controlling for the calorific value of fuel.

Recent NEPRA reports show that the average technical efficiency of private plants is about twice that of public plants, suggesting that the latter's generation capacity has declined (NEPRA, 2010). However, it is not clear whether the technical efficiency differential is manifested in the cost 
performance of power plants and the system's overall economic efficiency. In the absence of any other research, we can employ the reports published by the regulator and the available data to understand the comparative economic performance of power plants.

The Government of Pakistan's unbundling strategy for the stateowned utility WAPDA was intended to convert public plants into independent GENCOs that would then compete with private producers to supply electricity to the national grid. However, the failure of the corporatization of WAPDA has affected the financial independence and performance of government-owned public plants such that even routine services are not carried out on time. For instance, the failure to procure spare parts because of the GENCOs' lack of liquidity has resulted in poor plant operation and maintenance (O\&M) (NEPRA, 2010).

The regulator's reports show that existing public power plants need to be utilized around the clock, i.e., as base-load plants, in order to meet the persistent high demand over the year. The lack of mandatory shutdowns has resulted in poorly planned maintenance, with inadequate major overhauling, hot gas path inspections, combustion inspections, and annual boiler inspections. As a result, these plants run on partial load and forced outages increase.

The average availability from peak-load sharing to installed capacity varies from 42 to 58 percent for public plants, which is much lower than for private plants. The load factor-an important industry indicator defined as the ratio of total output to potential output at the maximum load assigned to a plant-also indicates the weak state of government plants. Their average load factor is 50 percent compared to 78 percent for private plants. The lower load factor (for a given amount of electricity produced) implies that the plant has to run longer in order to produce the given output, and this is likely associated with greater deterioration and higher fuel consumption.

The 1994 power policy stipulated a payment mechanism for privately owned electricity plants under which their power purchase agreements assured the producers of monthly capacity payments consisting of debt service, fixed O\&M costs, insurance, and return on equity on an internal rate of return basis, even if no electricity was purchased. In addition, private plants were to receive payment for energy purchased based on a per-unit energy charge. The upfront tariff mechanism, however, may have given producers incentive not to operate 
their least-cost supply plants as the tariff system was not based on a competitive framework of installing new generation capacity (Government of Pakistan, 1998).10 The IPPs probably forecasted that their plant factor during the initial years of production would be lower, given the growth in demand for electricity in the late 1990s, and that cash flows would thus depend on capacity price. How this affected their decision making during the investment process is not clear.

Labor efficiency can also be a factor in the efficiency differential between government-owned and privately owned plants. Private GENCOs may be well managed and have better human resources (see Lerner, Khwaja, \& Leamon, 2012). Anecdotal evidence tends to favor the transfer of experienced and skilled staff from public to private plants or elsewhere in the private sector-this is due to better incentives for engineering and nonengineering staff. The failure of the corporatization of WAPDA, however, raises doubts about any efficiency gains being associated with better human resource management in governmentowned plants (NEPRA, 2010). Similarly, the privatization of the KESC in 2005 may not have affected its labor management substantially, at least for the first few years. ${ }^{11}$

In the public sector, over-staffing and related costs tend to run high during the tenure of elected governments. Between 1999 and 2007, there was no major political change-the country underwent a mix of authoritarian and democratic structures-but the GENCOs that were part of WAPDA were exposed to political over-staffing before 1999 under successive democratic governments.

\section{Data and Related Issues}

Estimating plant-level, short-run variable cost efficiency requires sub-firm or unit-level data, collecting which involves the maximum possible disaggregation, given the data availability constraint. In the electricity industry, a plant can house several independent units of varying vintage. The definition of "plant" in this study depends on a mix of managerial, accounting, and regulatory contexts. For instance, nonutility

\footnotetext{
${ }^{10}$ It is less clear if the Averch-Johnson effect is present because nonutility-owned plants are, on average, smaller than utility-owned plants. The political motivation arises from the lack of transparency in firm selection while missing competitive bidding failed to filter out generation units on a least-cost basis (Fraser, 2005).

${ }^{11}$ The KESC's new management has tried to reduce over-staffing in the utility, but failed to do so as a result of political pressure (although the proposed staff reductions may not have pertained to the generation component of the utility).
} 
private plants are dispatched as a single unit while public plants are dispatched unit-wise or in blocks of units, depending on the fuel input used. Although unit-level data makes sense for examining short-run working-cost performance, in this analysis a plant can be an aggregate of several units or a single unit, depending on the availability of data.

Since the study focuses on oil- and gas-based power plants, the sample does not include plants producing hydroelectricity. Further, two nuclear plants and one coal plant have also been excluded due to possible differences in fuel cost and technology (compared to oil- and gas-based plants). The full sample includes 83 electricity generating plants/units that were operational between 2006 and 2011; the sample size is 356 plant-years. These power plants account for 68 percent of total electricity production in the country during the sample period.

Interestingly, the disaggregation in the available data matches the disaggregation required at plant level due to unit variations in vintage within plants. For instance, the variation in unit age within a plant is higher for public plants as is the disaggregated data available at the unit level; this enables us to capture any inefficiency differential in vintage. On the other hand, the data on nonutility-owned private plants is available at the aggregate plant level (aggregated for all units within a plant). Since most private firms started operation in a short span of time with the possibility of homogenous units within a plant, the chances of a cost-efficiency differential due to data disaggregation at the unit level for public plants and data aggregation for private plants are reduced, if not eliminated.

The data needed to estimate the variable cost function includes fuel prices, fuel consumption, total wage bill (labor cost), and variable maintenance expenditure. In addition, data on the total cost of production, total electricity generated, and maximum plant load assigned is required at the plant level. Our main sources of data are the reports published by NEPRA, the National Transmission and Dispatch Company (NTDC), and the KESC (see Table A1 in the Appendix for a complete list of variables). NEPRA's state-of-industry reports include plant-level data on generating capacity, the electricity generated in a year, fuel quantity, and load factor.

One important point to note for our analysis is that, although detailed information on the required variables is available for the majority of government-owned plants, there is no data on the O\&M expenditure and labor cost variables of IPPs. Since we focus on oil- and gas-run plants, the fuel expenditure is likely to be the most important component of total 
variable cost. This is intuitive, given that fuel costs account for about 94 and 93 percent, respectively, of the total variable cost for the given sample of public and private plants. ${ }^{12}$

\section{Empirical Production Model}

In the case of a single-output production process, one can assess productive efficiency by observing whether the firm is maximizing its output, given the inputs, and if it employs the best mix of inputs, given input prices. The production function describes the various possibilities for transforming inputs into output, but without taking into account the relative prices of inputs. On the other hand, cost minimization assumes that firms minimize their production costs for a given level of output by incorporating input prices. An electricity plant might be producing the maximum electricity possible using a given mix of plant, material, fuel, and labor, but it may not be minimizing its costs if the labor is cheaper than the material while the plant uses more material and less labor.

Even if different types of fuel are used to produce heat input, it is cost-effective to use the cheaper fuel for a given amount of heat produced. Thus, if it is possible to produce the same level of output by using more labor and less material or a different fuel, then the plant can lower its costs by employing a different mix of inputs. Therefore, an efficient electricity generating plant will minimize the cost of producing any amount of electricity, given input prices.

The study's productive efficiency comparison between utilityowned and nonutility-owned (private) electricity generation plants is based on cost function specifications. The duality between the production function and cost function allows econometricians to recover production parameters from the cost function under certain regularity conditions (Diewert, 1971). Similarly, the cost minimizing factor demand expressions can be derived from the production function.

Nerlove (1963) and Christensen and Greene (1976) are among the earliest applications of the duality theory in empirical analyses of the electricity industry. Their rationale hinges on the exogeneity of both factor prices and electricity output: this is because factor prices are typically determined in competitive markets or through regulation, while electricity output is determined mainly by the load demand. Therefore, fuel prices

\footnotetext{
${ }^{12}$ The estimate for private plants is based on the fuel cost component and O\&M cost component of the upfront power tariff.
} 
and electricity output are not related with unobserved heterogeneity in the cost function. Estimating the production function complicates matters as inputs become endogenous for the plant manager, requiring a full structural specification to consistently estimate the technology parameters (Markiewicz et al., 2004). Given the limited data available for Pakistan, a structural estimation of the production function is not feasible.

Recent empirical studies in the industrial organization literature have employed cost function estimations to address various performancerelated issues in the industry (Maloney, 2001). Estimating a cost function can be a good starting point for building baseline knowledge about the performance of the power generation industry in Pakistan. Price and output exogeneity ${ }^{13}$ appear to be credible assumptions in the case of Pakistan as plants are forced to produce the required electricity and profit maximization does not seem plausible. The oil and gas regulator controls fuel prices while the power generator purchases fuel according to its plant technology.

Plant ownership, however, can change the level of the cost function: as mentioned in the NEPRA reports, utility-owned plants may generate a particular amount of electricity at a higher cost compared to nonutilityowned plants. In order to improve average unit cost comparisons, an econometric cost function can control for all the observed relevant factors. These different empirical comparisons along with their summary statistics are discussed below.

Following Foreman-Peck and Waterson (1985), we specify a simplified form of the trans-log cost function as a goal function, which extends Christensen and Greene's (1976) study. The trans-log framework can also be used to study substitution effects, scale effects, and technological changes (Greene, 1980). The specification proposed here is informative as it incorporates the effect of the load factor on the average unit cost of electricity generation.

The load factor (load) is defined as the total electricity output $(q)$ in a period, divided by the product of the maximum load $(m)$ and the time the plant remains connected to the load $(v)$ : load $=q / m^{*} v$. Load factor is an important factor affecting the cost of electricity generation (Foreman-Peck

\footnotetext{
${ }^{13}$ The variation in fuel prices in Table 1 is partly a result of the fuel mix (gas and oil) and partly due to the nature of contracts with gas suppliers. On average, gas and oil prices are reflected by exogenous market forces and by competitive fuel demand in the economy. Therefore, prices are potentially exogenous in short-run cost functions.
} 
\& Waterson, 1985). The adapted version of the trans-log cost function is given below in equation (1):

$$
\begin{aligned}
& \log \left(c_{i t}\right)=\alpha+\beta \log \left(q_{i t}\right)+\beta_{2}\left(\log \left(q_{i t}\right)\right)^{2}+\beta_{3} \log \left(p_{i t}\right)+\gamma \log \left(\operatorname{load}_{i t}\right) \\
& +\lambda \log \left(\text { age }_{i t}\right)+\text {.private }_{i}+\sum_{t=2}^{T} \rho T_{t}+u_{i t} \\
& i=1,2, \ldots N ; t=1,2, \ldots T
\end{aligned}
$$

where $C$ is the unit cost of production (in PRs per kWh), $p$ is the fuel price per million British thermal units (MMBTUs), age is the vintage of the plant, and private is an ownership dummy that takes a value of 1 if the plant is owned by a private firm and 0 if the plant is owned by a public GENCO.

The electricity output is scaled in kilowatt-hours while capacity utilization is based on the maximum load in kilowatts and the proportion of time the plant remained connected to the load. Recent studies have employed different expressions of capacity utilization: for instance, Maloney (2001) adds the term "intermittent idling" (electricity generation time as a proportion of the total time in the year) to equation 1 (given above). This term may be more useful when coal-based generation is high, which is not the case in Pakistan.

The above specification is estimated for fuel unit costs only because the funds allocated to fuel input in fossil fuel-based power generation are likely to be substantial. This intuition is supported by the available data: on average, 93 percent of total variable expenditure can be attributed to fuel costs both for public and private power plants. There is also limited data available on the price indices for labor and maintenance costs of private power plants.

\section{Findings and Results}

Table 1 gives the summary statistics for the variables used in the regression analysis. These are based on a sample of public and private plants for plant-years with positive production and nonzero fuel inputs. The private plants are subdivided into utility-owned and nonutility-owned groups, where the utility-owned plants fall under the KESC.

The summary statistics presented in the table are for an aggregate sample and may miss variations across plants over time. On the other hand, public plants produce electricity at a higher average unit cost (PRs 
per $\mathrm{kWh}$ ) than private plants. There are also substantial differences in average plant age according to plant ownership.

Table 1: Summary statistics for power plants

\begin{tabular}{lcrrrr}
\hline Variable & Observations & Mean & SD & Min. & Max. \\
\hline Government plants & & & & & \\
Output (GWh) & 184 & 506.9 & 456.8 & 0.5 & $1,887.1$ \\
Unit output cost (PRs per kWh) & 184 & 3.8 & 2.1 & 0.8 & 10.6 \\
Fuel price (PRs per MMBTU) & 184 & 295.7 & 182.7 & 41.1 & 798.0 \\
Load factor (\%) & 184 & 49.1 & 26.6 & 0.2 & 97.0 \\
Plant age (years) & 184 & 27.9 & 10.2 & 10.0 & 51.0 \\
\hline Private plants (IPPs) & & & & & \\
Output (GWh) & 73 & $2,121.0$ & $2,402.1$ & 50.4 & $9,140.8$ \\
Unit output cost (PRs per kWh) & 73 & 3.6 & 1.8 & 0.6 & 7.1 \\
Fuel price (PRs per MMBTU) & 73 & 429.2 & 209.2 & 73.4 & 839.8 \\
Load factor (\%) & 73 & 77.2 & 18.3 & 5.1 & 98.6 \\
Plant age (years) & 73 & 10.4 & 3.0 & 1 & 19.0 \\
\hline Private plants (utility-owned) & & & & & \\
Output (GWh) & 99 & 451.1 & 477.3 & 0.1 & $1,553.5$ \\
Unit output cost (PRs per KWh) & 99 & 2.9 & 1.1 & 1.3 & 8.7 \\
Fuel price (PRs per MMBTU) & 86 & 223.5 & 101.6 & 126.5 & 705.1 \\
Load factor (\%) & 98 & 82.4 & 8.8 & 49.4 & 96.8 \\
Plant age (years) & 99 & 22.6 & 11.3 & 1.0 & 42.0 \\
\hline
\end{tabular}

Note: Estimates based on plant-year data for 2006 to 2011. 1 MMBTU $\approx 293 \mathrm{kWh}$.

Source: Author's calculations.

Figure 1: Fuel sources for electricity production, 2006-12 (\%)

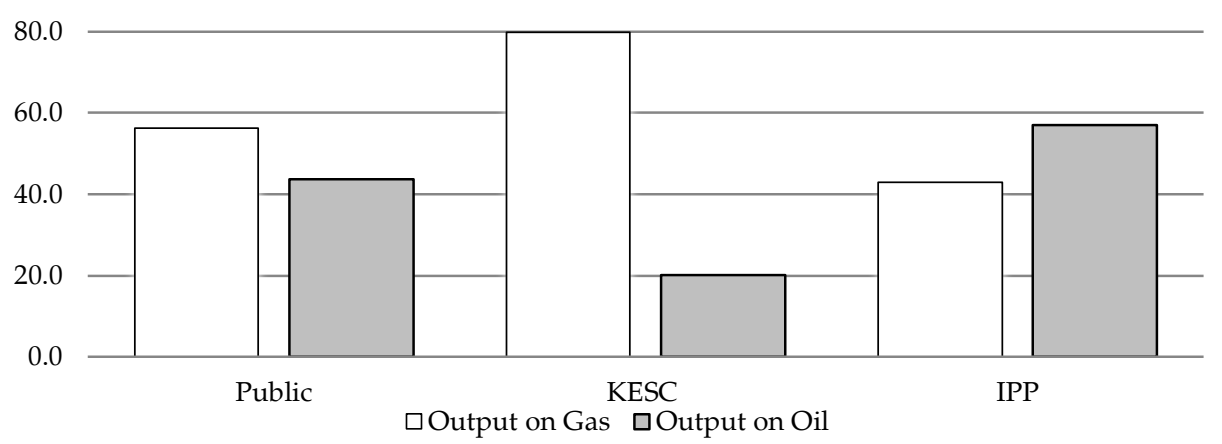

Source: National Electric Power Regulatory Authority, Annual Reports (2010, 2011).

Cost function specification (1) described in the previous section is employed to produce regression estimates for public and private plants. 
The results for the three comparisons are presented in Table 2. Column (1) compares all public and private power plants; columns (2) and (3) compare public plants and IPPs, and public plants and utility-owned private plants, respectively.

Table 2: Comparison of pooled regression estimates of cost function

\begin{tabular}{lllllll} 
& \multicolumn{7}{c}{ Dependent variable = log output unit cost } \\
\hline & \multicolumn{7}{c}{ Cost specification } \\
\cline { 2 - 7 } Explanatory variable & \multicolumn{1}{c}{$(\mathbf{1})$} & \multicolumn{1}{c}{$\mathbf{( 2 )}$} & \multicolumn{1}{c}{$\mathbf{( 3 )}$} & $\mathbf{( 4 )}$ & \multicolumn{1}{c}{$\mathbf{( 5 )}$} & \multicolumn{1}{c}{$\mathbf{( 6 )}$} \\
\hline Log fuel prices & $0.902^{* * *}$ & $0.873^{* * *}$ & $0.884^{* * *}$ & $0.880^{* * *}$ & $1.025^{* * *}$ & $0.977^{* * *}$ \\
& $(0.02)$ & $(0.022)$ & $(0.02)$ & $(0.021)$ & $(0.027)$ & $(0.058)$ \\
Log electricity output & -0.321 & $-0.471^{*}$ & -0.375 & -0.304 & -0.441 & 0.793 \\
& $(0.191)$ & $(0.204)$ & $(0.246)$ & $(0.259)$ & $(0.822)$ & $(0.533)$ \\
Square of log electricity & 0.005 & 0.01 & 0.007 & 0.005 & 0.01 & -0.022 \\
output & $(0.005)$ & $(0.005)$ & $(0.006)$ & $(0.007)$ & $(0.019)$ & $(0.014)$ \\
Log load factor & 0.043 & 0.05 & 0.04 & 0.054 & 0.002 & 0.236 \\
& $(0.024)$ & $(0.029)$ & $(0.023)$ & $(0.034)$ & $(0.085)$ & $(0.199)$ \\
Age of plant & -0.001 & 0.0004 & 0.0001 & -0.002 & 0.009 & $0.009^{* * *}$ \\
& $(0.001)$ & $(0.002)$ & $(0.002)$ & $(0.002)$ & $(0.004)$ & $(0.002)$ \\
Age of plant * private plant & $0.015^{* * *}$ & $0.013^{*}$ & $0.009^{* * *}$ & & & \\
interaction & $(0.002)$ & $(0.006)$ & $(0.002)$ & & & \\
Dummy for private plant & $-0.330^{* * *}$ & $-1.239^{* * *}$ & $-0.153^{* *}$ & & & \\
& $(0.053)$ & $(0.163)$ & $(0.055)$ & & & \\
Log fuel prices * private & & $0.147^{* * *}$ & & & & \\
plant interaction & & -0.032 & & & & \\
Constant & 0.208 & 1.657 & 0.691 & 0.264 & 0.003 & $-12.329^{*}$ \\
& $(1.841)$ & $(1.949)$ & $(2.298)$ & $(2.362)$ & $(8.455)$ & $(5.6)$ \\
Observations & 343 & 257 & 270 & 184 & 73 & 86 \\
$\mathrm{R}^{2}$ & 0.945 & 0.960 & 0.943 & 0.947 & 0.987 & 0.926 \\
\hline
\end{tabular}

Notes: The estimates are based on a pooled sample for 2006 to $2011 .{ }^{*} \mathrm{p}<0.05,{ }^{* *} \mathrm{p}<0.01$, *** $\mathrm{p}<0.001$. Standard errors are clustered at the plant level and reported in parentheses below the coefficients.

Column (1) = overall sample, (2) = private IPPs and public plants, (3) = public and utilityowned private plants (KESC), (4) = public plants only, (5) = IPPs only, (6) = utility-owned (KESC) private plants.

Source: Author's calculations.

The performance differential between public and private plants should be reflected in the difference in slope coefficients or in an intercept shift or both for the estimated cost function. The results of the structural stability tests do not accept the hypothesis of equal coefficients between public and private plants for the year dummies and vintage coefficients for the three comparisons mentioned above. Further, the coefficient of log 
prices is also statistically different for nonutility private plants (IPPs) and public plants in column (2) of Table 2.

The analysis yields the regression results in columns (1), (2), and (3) of Table 2 after allowing for separate vintage effects for private plants and for the adjustment of separate slope coefficients for fuel prices in column (2). The log fuel price coefficient is statistically significant in all the models and the estimated price elasticity of the average unit cost for the full sample is 0.90 . This shows a percentage change of $<1$ to 1 in average unit cost with respect to the change in fuel price. In column (5), the estimated fuel price elasticity for utility-owned private IPPs is higher than for public plants. The price elasticity of the unit output cost is also higher for utility-owned private plants in column (6).

The estimated plant vintage coefficients for public and private plants are statistically different: -0.001 and 0.014 , respectively. The impact of private plant aging on the unit cost is positive, which implies that the newest IPP plant will produce at a 26.6 percent lower average unit cost than the oldest IPP plant, holding other factors constant. The vintage coefficient for public plants is not statistically significant, indicating no substantial impact of plant aging on their unit cost. However, the public plants in the sample are older than most of the private plants and, due to deterioration over the years, the former group consists of technically inefficient and homogenous plants.

In a cost function scale, economies can be evaluated on the basis of output coefficients. The output and output-squared coefficients have the expected signs but are not statistically significant in most of the regressions in Table 2, except column (2). Therefore, there is no clear evidence of a scale effect on cost reduction for public and private plants. However, the subsample of gas-run plants demonstrates substantial scale economies as shown in Table A2 in the Appendix. There might be potential confounding between scale economies and vintage: the IPP plants running on gas are younger and larger while the public plants operating on gas are fairly old and smaller. The estimated scale economies $S C E=1-\partial \log (c) / \partial \log (q)$ are presented in Table 3 below. 
Table 3: Economies of scale for gas-based units

\begin{tabular}{lcc}
\hline Unit & SCE & Standard error \\
\hline All plants & $1.14^{* * *}$ & 0.02 \\
WAPDA system & $1.10^{* * *}$ & 0.02 \\
Public plants and KESC plants & $1.00^{* * *}$ & 0.04 \\
\hline
\end{tabular}

Note: ${ }^{* *} \mathrm{p}<0.001$.

Source: Author's calculations.

The estimate for the plant ownership dummy in column (1) of Table 2 indicates that private plants in the system produce electricity at a lower (33 percent less) unit fuel cost than public plants, after allowing for different slope coefficients for the year dummies and plant vintage, and controlling for other observable factors. Similarly, the results in column (2) show that public plants produce electricity at a substantially higher average unit cost compared to private IPP plants. The bulk of nonutilityowned private IPPs fall within the WAPDA system where private plants produce electricity at a substantially lower unit fuel cost than public plants.

The comparison between private plants owned by the KESC 14 and public plants in the WAPDA system is given in column (3); the estimates show that the average unit cost for private utility-owned plants is 15 percent less than that for public plants. The results for public-, IPP-, and utility-owned private plants (KESC plants) are given in the last three columns of Table 2, respectively. However, the standard errors of the individual results in columns (5) and (6) may be problematic due to the small number of clusters for IPP plants and utility-owned private plants.

The regression results in columns (1) and (3) of Tables 2 and A2 indicate the risk of selective privatization of utility-owned plants, although most of the plant-year sample data for KESC-owned plants refers to older plants comparable in vintage to public-owned plants. The results in column (2) of Tables 2 and A2 do not give the risk of ownership selection as the private plants in the subsamples were established by IPPs.

Estimating a fully specified variable cost function is not possible due to the unavailability of data on labor and maintenance costs for private plants. However, in order to assess the impact of nonfuel costs on the total

\footnotetext{
${ }^{14}$ The two main systems are the WAPDA or NTDC system and the KESC system. The KESC grid is interconnected to the NTDC grid system through two double-circuit $220 \mathrm{KV}$ transmission lines. On average, the KESC purchased $330 \mathrm{GWh}$ annually from the WAPDA system during 2005-10.
} 
cost, Table A3 in the Appendix gives estimates for the fully specified variable cost function for the subsample of government-owned plants.

In Table A3, the wage bill reflects the per-unit cost of labor and the maintenance bill reflects the per-unit maintenance cost. The wage bill is calculated by dividing total wages and salaries by plant/unit output; the maintenance bill is calculated by dividing the total maintenance cost by plant/unit output. The proportionate change in the electricity unit cost or elasticity with respect to the fuel price, wage bill, and maintenance bill is $0.88,0.01$, and -0.04 , respectively. The results show that the wage cost has an insignificant impact on electricity production costs. There is also an indication that, as maintenance expenses per unit produced increase, the cost of production declines. This result demonstrates the importance of timely maintenance expenses for increasing plant efficiency.

The regulator's reports present data on the declining fuel efficiency of public plants in the WAPDA system on the basis of technical efficiency alone. This leaves room to interpret that these plants operated at low cost because they were generating electricity with gas as their fuel input (which is relatively cheap). The evidence on their economic efficiency, however, reinforces the notion that public plants are not only less technically efficient, but are also economically inefficient, particularly relative to the IPPs in the system. Further, the estimates in Table A2 show that gas-based public plants produce electricity at a higher average unit cost than privately owned gas-based plants. Therefore, the fuel allocation policy, and in particular the gas supply policy, needs to be reconsidered such that scarce gas fuel is supplied to cost-efficient plants wherever possible.

The results in Tables 2 and A2 need to be qualified, which may have some important implications as well. The analysis is based on the short-run cost function, which uses the fuel cost to proxy the total variable cost; any implications should thus be considered in this context. The private IPP plants are newer than the public plants and WAPDA's GENCOs have not invested in new public plants or in any major repair plan for the existing units (which are fairly old) since industry reforms were introduced in the early 1990s. ${ }^{15}$

The absence of data on wage bills and routine maintenance for private plants constrains the estimation of a fully specified short-run variable cost function. Future research will require the collection of detailed

15 The only young public plant, the Kot Addu power plant, was completed in 1996, but then privatized. The GENCO plants are now being revamped with funds supplied by USAID. 
cost information on private plants in order to incorporate price indices for wage bills and plant maintenance. Moreover, our findings do not necessarily imply that privatization will improve the efficiency of a given plant. Proposing policies such as the recent option to transform public plants into privately managed units will require a further understanding of the issues that underlie the low efficiency of public plants.

\section{Concluding Remarks}

The study's estimation of a cost function for power plants is an attempt to compare plant performance according to plant ownership in Pakistan's electricity industry. Our results show that public plants are less efficient than private plants, both technically and economically. This does not, however, imply that the latter perform better on other dimensions of cost, including wage bills and maintenance, because this exercise was based on the limited information available, particularly for private plants.

To assess the cost of private production to the final supply of electricity, further research is needed to analyze the long-term contracts between IPPs and the central power purchase company. Although the public plants are owned by public companies, i.e., GENCOs, their management still falls under a vertically integrated utility. Dynamic issues in the regulation of other components of the utility and issues relating to transmission and distribution are likely to have affected the functioning of public power firms and thereby the plants they run.

The current state of public plants also needs to be looked at in the historical context of industry reforms and vanishing new investments either to repair existing plants or set up modern vintage sets. Given that the public plants are still effectively part of a vertically integrated utility, their lack of financial independence and related tariff issues need to be better understood for future reforms. 


\section{References}

Bloom, N., \& Van Reenen, J. (2010). Why do management practices differ across firms and countries? Journal of Economic Perspectives, 24(1), 203-224.

Christensen, L. R., \& Greene, W. H. (1976). Economies of scale in US electric power generation. Journal of Political Economy, 84(4), 655-676.

Diewert, W. E. (1971). An application of the Shephard duality theorem: A generalized Leontief production function. Journal of Political Economy, 79(3), 481-507.

Foreman-Peck, J., \& Waterson, M. (1985). The comparative efficiency of public and private enterprise in Britain: Electricity generation between the World Wars. The Economic Journal, 95, 83-95.

Fraser, J. M. (2005). Lessons from the independent private power experience in Pakistan (EMSB Discussion Paper No. 14). Washington, DC: World Bank.

Government of Pakistan. (1994). Policy framework and package of incentives for private sector power generation projects in Pakistan. Islamabad: Author.

Government of Pakistan. (1998). Policy for new private independent power projects. Islamabad: Author.

Greene, W. H. (1980). On the estimation of a flexible frontier production model. Journal of Econometrics, 13(1), 101-115.

Greene, W. H. (2008). The econometric approach to efficiency analysis. In H. O. Fried, C. A. Knox Lovell, \& S. S. Schmidt (Eds.), The measurement of productive efficiency and productivity growth (chap. 2). Oxford: Oxford University Press.

Joskow, P. L. (1997). Restructuring, competition and regulatory reform in the US electricity sector. Journal of Economic Perspectives, 11(3), 119138.

Joskow, P. L., \& Schmalensee, R. (1983). Markets for power: An analysis of electrical utility deregulation. Cambridge, MA: MIT Press. 
Laffont, J.-J., \& Tirole, J. (1993). A theory of incentives in procurement and regulation. Cambridge, MA: MIT Press.

Lerner, J., Khwaja, A. I., \& Leamon, A. (2012). Abraaj Capital and the Karachi Electric Supply Company (Harvard Business School Case No. 812-019). Cambridge, MA: Harvard Business School.

Malik, A. (2007). Effectiveness of regulatory structure in the power sector of Pakistan (Working Paper No. 25). Islamabad: Pakistan Institute of Development Economics.

Maloney, M. T. (2001). Economies and diseconomies: Estimating electricity cost functions. Review of Industrial Organization, 19(2), 165-180.

Markiewicz, K., Rose, N. L., \& Wolfram, C. (2004). Do markets reduce costs? Assessing the impact of regulatory restructuring on US electric generation efficiency (Working Paper No. 11001). Cambridge, MA: National Bureau of Economic Research.

Megginson, W. L., \& Netter, J. M. (2001). From state to market: A survey of empirical studies on privatization. Journal of Economic Literature, 39(2), 321-389.

National Electric Power Regulatory Authority. (2010). State of industry report 2010. Islamabad: Author.

National Electric Power Regulatory Authority. (2011). State of industry report 2011. Islamabad: Author.

Nerlove, M. (1963). Returns to scale in electricity supply. In C. F. Christ et al. (Eds.), Measurement in economics: Studies in mathematical economics and econometrics in memory of Yehuda Grunfeld. Stanford, CA: Stanford University Press.

Saleem, M. (2007). Benchmarking and regulation for the electricity distribution sector in Pakistan: Lessons for developing countries. South Asia Economic Journal, 8(1), 117-138.

World Bank. (2010). Enterprise surveys [Database]. Retrieved from http:/ / data.worldbank.org/data-catalog/enterprise-surveys 


\section{Appendix}

Table A1: List of variables

\begin{tabular}{ll}
\hline Variable & Unit \\
\hline Installed capacity & $\mathrm{MW}$ \\
Dependable capacity & $\mathrm{MW}$ \\
Units generated & $\mathrm{GWh}$ \\
Auxiliary consumption from own system & $\mathrm{GWh}$ \\
Auxiliary consumption from other systems & $\mathrm{GWh}$ \\
Units sent out & $\mathrm{GWh}$ \\
Gross heat rate & \\
Net heat rate & \\
Gross efficiency & $\%$ \\
Net efficiency & $\%$ \\
Shutdown hours & Hours \\
Total running hours & Hours \\
Maximum load & MW \\
Plant load factor & $\%$ \\
Plant utilization factor & $\%$ \\
Plant capacity factor & $\%$ \\
Plant availability factor & $\%$ \\
Gas consumed & MCF \\
HSD consumed & Liter \\
RFO consumed & Mton \\
\hline
\end{tabular}




\section{Figure A1: Unit fuel prices}

Fuel Price (Rupee Per MMBTU) Fuel Price (Rupee Per MMBTU)

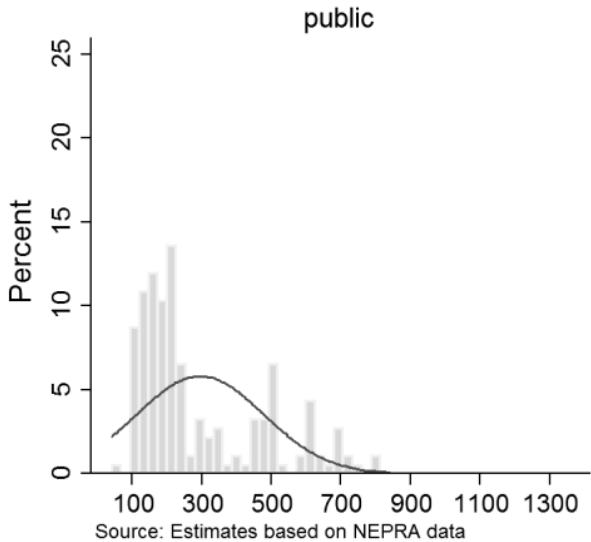

private

price of fuel Rs/MMBTU

\begin{tabular}{|l|}
\hline Percent \\
normal pbtu
\end{tabular}

Graphs by dummy for private owned plant

\section{Figure A2: Unit fuel costs}

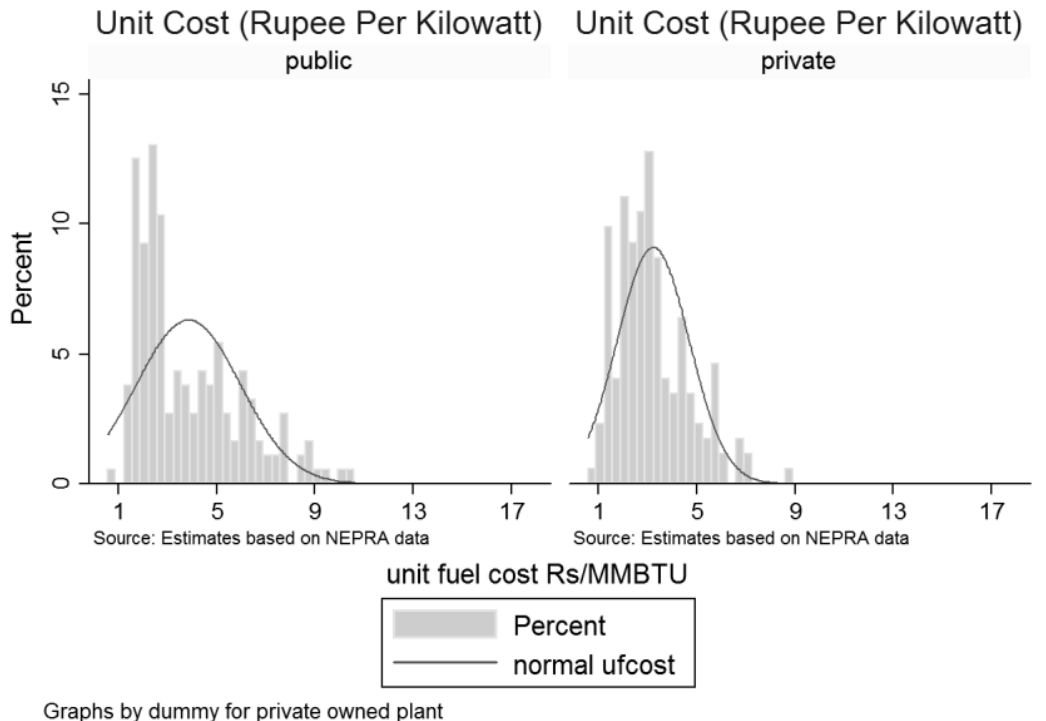


Table A2: Comparison of pooled regression estimates of cost function

\begin{tabular}{llll}
\multicolumn{3}{c}{ Dependent variable $=\log$ output unit cost (plants running on gas) } \\
\hline \multirow{2}{*}{ Explanatory variable } & \multicolumn{3}{c}{ Cost specification } \\
\cline { 2 - 4 } Log fuel prices & \multicolumn{1}{c}{$\mathbf{( 1 )}$} & \multicolumn{1}{c}{$\mathbf{( 2 )}$} & \multicolumn{1}{c}{$\mathbf{( 3 )}$} \\
\hline Log electricity output & $(0.029)$ & $(0.033)$ & $(0.033)$ \\
& $-0.501^{* * *}$ & $-0.777^{* * *}$ & $-0.883^{* * *}$ \\
Square of log electricity output & $(0.189)$ & $(0.185)$ & $(0.231)$ \\
& 0.009 & $0.017^{* * *}$ & $0.021^{* *}$ \\
Log load factor & $(0.005)$ & $(0.005)$ & $(0.006)$ \\
& 0.043 & 0.042 & 0.034 \\
Age of plant & $(0.024)$ & $(0.023)$ & $(0.018)$ \\
& $-0.008^{* *}$ & -0.005 & -0.001 \\
Age of plant * private plant interaction & $(0.003)$ & $(0.003)$ & $(0.004)$ \\
& $0.021^{* * *}$ & $0.014^{*}$ & $0.011^{*}$ \\
Dummy for private plant & $(0.003)$ & $(0.006)$ & $(0.004)$ \\
& $-0.581^{* * *}$ & $-1.087^{* * *}$ & -0.195 \\
Log fuel prices * private plant interaction & $(0.084)$ & $(0.216)$ & $(0.119)$ \\
& & $0.083^{*}$ & \\
Constant & & $(0.039)$ & \\
Observations & 2.418 & $4.710^{*}$ & $5.515^{*}$ \\
$\mathrm{R}^{2}$ & $(1.856)$ & $(1.827)$ & $(2.114)$ \\
\hline
\end{tabular}

Notes: The estimates are based on a pooled sample for 2006 to $2011 .{ }^{*} p<0.05,{ }^{* *} p<0.01$, ${ }^{* * *} \mathrm{p}<0.001$. Standard errors are clustered at the plant level and reported in parentheses below the coefficients.

Column (1) = overall sample, (2) = private IPPs and public plants, (3) public and utilityowned private plants (KESC).

Source: Author's calculations. 


\section{Table A3: Pooled regression estimates of fully specified variable cost function}

Dependent variable $=$ log output unit cost (government-owned plants)

\begin{tabular}{lc}
\hline Explanatory variable & Estimates \\
\hline Log fuel prices & $1.982^{* * *}$ \\
& $(0.222)$ \\
Log wage bill & $0.332^{*}$ \\
Log maintenance bill & $(0.137)$ \\
& $-0.899^{* * *}$ \\
Log electricity output & $(0.084)$ \\
& $-0.777^{* * *}$ \\
Square of log electricity output & $(0.094)$ \\
& $0.030^{* * *}$ \\
Log fuel price * log wage bill & $(0.004)$ \\
& $-0.046^{*}$ \\
Log fuel price * log maintenance bill & $(0.022)$ \\
Log wage bill * log maintenance bill & -0.021 \\
& $(0.014)$ \\
Log output ${ }^{*} \log$ fuel price & $0.083^{* * *}$ \\
Log output ${ }^{*} \log$ wage bill & $(0.007)$ \\
Log output * $\log$ maintenance bill & $-0.065^{* * *}$ \\
Constant & $(0.012)$ \\
Observations & 0.009 \\
\hline
\end{tabular}

Notes: The estimates are based on a pooled sample of government-owned plants for 2006 to 2011. ${ }^{*} \mathrm{p}<0.05,{ }^{* *} \mathrm{p}<0.01,{ }^{* * *} \mathrm{p}<0.001$. Standard errors are clustered at the plant level and reported in parentheses below the coefficients. Year dummies are included in the regression to control for time variation. The wage bill is calculated by dividing the total wage bill by plant/unit output. The maintenance bill is calculated by dividing the wage bill by plant/unit output.

Source: Author's calculations. 


\section{Table A4: List of plants used in empirical analysis}

\section{Public plants}

- GTPS Faisalabad (units 1 to 8 )

- GTPS Kotri (units 1 to 6 )

- NGPS Multan (units 1, 3, 4, and 5)

- SPS Faisalabad (units 1 and 2)

- TPS Guddu (units 1 to 4 and 9 to 12)

- TPS Jamshoro (units 1 to 4 )

- TPS Muzaffargarh (units 1 to 6)

Private IPPs

- AES Lal Pir Limited

- AES Pak Gen (Private) Limited

- Altern Energy Limited

- Engro Energy Limited

- Fauji Kabirwala Power Company Limited

- Gul Ahmed

- Habibullah Costal Power Company Limited

- Hub Power Company (HUBCO)

- Japan Power Generation Limited

- Kot Addu Power Company (KAPCO)

- Kohinor Energy Limited

- Rousch Pakistan (Power) Limited

- Saba Power Company

- Southern Electric Power Company

- Tapal Energy

- Liberty Power Limited

- Uch Power Limited

KESC plants (utility-owned)

- Bin Qasim Thermal Power Station (units 1 to 6)

- Korangi GTPS (units 1 to 4 )

- Korangi CCGT (units 1 to 4)

- Korangi GTPS II

- Korangi Thermal Power Station (units 1,3, and 4)

- SITE GTP (units 1 to 5)

- SITE GTPS II 